\title{
KEMAMPUAN PENALARAN MATEMATIKA DITINJAU DARI TIPE KEPRIBADIAN HIPPOCRATES PADA MAHASISWA PROGRAM STUDI PENDIDIKAN MATEMATIKA
}

\author{
Hafsyah $^{1}$, Hasnidar ${ }^{2}$, Putriyani $S^{3}$ \\ 1,3 (Program Studi Pendidikan Matematika, Universitas Muhammadiyah Enrekang) \\ .2(Program Studi Bimbingan dan Konseling, Universitas Muhammadiyah Enrekang \\ * Corresponding Author. E-mail: ${ }^{1}$ putriyani49@gmail.com
}

\begin{abstract}
Abstrak
Penelitian ini bertujuan untuk mengetahui kemampuan penalaran mahasiswa yang ditinjau dari tipe kepribadian Hippocrates. Penelitian yang melibatkan mahasiswa semester IV Program Studi Pendidikan Matematika termasuk dalam jenis penelitian deskriptif. Penelitian diawali dengan pemberian tes kepribadian untuk memilih subjek penelitian. Berdasarkan hasil tes kepribadian tersebut siswa terbagi menjadi empat kelompok kepribadian, yaitu: sanguinis (S), koleris (K), melankholis (M), dan plegmatis $(P)$. Selanjutnya, tes tertulis masalah matematika diberikan untuk memperoleh kemampuan penalaran dari subjek penelitian. Hasil tes tertulis dianalisis berdasarkan langkah-langkah pemecahan masalah yang dikemukakan oleh Polya dengan indikator-indikator kemampuan penalaran. Untuk menggali lebih dalam tentang kemampuan penalaran mahasiswa, dilakukan wawancara secara mendalam dengan mengacu pada hasil tes tertulis masalah matematika. Hasil penelitian menggambarkan kemampuan penalaran mahasiswa berdasarkan tipe kepribadianya. Tipe $S$ cenderung menggunakan simbol matematika dalam menyelesaikan masalah, dan mempunyai lebih dari satu cara pada setiap masalah yang diberikan. Tipe $K$ menyelesaikan masalah langsung pada inti pertanyaan dan mempunyai lebih dari satu cara penyelesaian. Tipe $M$ cenderung memerinci masalah dalam bentuk tulisan dan hanya mempunyai satu cara penyelesaian. Tipe $P$ mampu menyampaikan langkah penyelesaian masalah dengan lengkap dan jelas, serta mempunyai lebih dari satu cara penyelesaian. Hasil penelitian ini menjadi referensi bagi dosen dalam menyusun dan mengembangkan program perkuliahan yang mengakomodasi tipe kepribadian dan meningkatkan kemampuan penalaran mahasiswa melalui strategi pembelajaran.
\end{abstract}

Kata Kunci: Kemampuan Penalaran, Tipe Kepribadian, Hippocrates

\section{Abstract (English-Indonesia)}

The research aimed to determine students 'reasoning abilities in terms of Hippocrates' personality type. Research involved fourth-semester students of the Mathematics Education Program is descriptive research. The research began with giving personality tests to select research subjects. Then, students are divided into four personality groups, namely: sanguine $(S)$, choleric $(C)$, melancholy $(M)$, and phlegmatic $(P)$. Furthermore, a written test of mathematical problems is given to obtain the reasoning abilities of the research subject. The written test results were analyzed based on the problem-solving steps put forward by Polya with indicators of reasoning ability. To dig deeper into students' reasoning abilities, in-depth interviews were conducted with reference to the 
written test results of math problems. The results of the study described students' reasoning abilities based on their personality types. Type S tended to use mathematical symbols in solving problems and had more than one way of dealing with any given problem. Type $K$ solved problems right to the point of the question and had more than one solution. Type $M$ tended to detail problems in writing and had only one solution. Type $P$ was able to convey problem-solving steps completely and clearly and had more than one solution. The results of this study became a reference for lecturers in preparing and developing lecture programs that accommodated personality types and improve students' reasoning abilities through learning strategies.

Keywords: reasoning ability, Hippocrate's personality type 


\section{Pendahuluan}

Standar NCTM (OECD, 2014)
mengemukakan bahwa standar utama
pembelajaran matematika yaitu kemampuan
pemecahan masalah,
komunikasi, kemampuan
kemampuan penalaran, dan kemampuan
representasi. Berdasarkan standar di atas
bahwa salah satu tujuan mata pelajaran
matematika di sekolah adalah menggunakan
penalaran pada pola dan sifat, melakukan
manipulasi matematika dalam membuat
generalisasi, menyusun bukti, atau
menjelaskan gagasan dan pernyataan
matematika. Hal ini berarti penalaran
matematika adalah fondasi untuk
mendapatkan atau menkonstruk pengetahuan matematika. Dengan demikian mahasiswa sebagai calon guru sekolah menengah harus mengembangkan kemampuan penalaran siswa dalam pembelajaran matematika.

Kemampuan penalaran Matematika adalah kemampuan menghubungkan antara ide-ide atau objek-objek Matematika, membuat, menyelidiki dan mengevaluasi dugaan Matematika, serta mengembangkan argumen-argumen dan bukti-bukti Matematika untuk meyakinkan diri sendiri dan orang lain bahwa dugaan yang dikemukakan adalah benar (Subanindro, 2012). Ditambahkan oleh Ramdani bahwa kemampuan penalaran Matematika meliputi: (1) memberikan penjelasan terhadap model, gambar, fakta, sifat, hubungan, atau pola yang ada; (2) memperkirakan jawaban dan proses solusi, dan menggunakan pola dan hubungan untuk menganalisis situasi matematik, menarik analogi dan generalisasi; (3) menyusun dan menguji konjektur, memberikan lawan contoh; dan (4) mengikuti aturan inferensi, menyusun argumen yang valid, memeriksa validitas argumen (Ramdani, 2012). Pendapat yang lain, Sihotang menjelaskan yang termasuk kegiatan penalaran Matematika meliputi: 1) mengumpulkan fakta; 2) membuat konjektur; 3) menetapkan generelisasi; 4) membangun argumen; 5) menetapkan kesimpulan logis berdasarkan ide atau gagasan dan hubunganhubungannya (Sihotang, 2011).

Kemahiran siswa dalam memecahkan masalah matematis, dipengaruhi oleh kemampuannya dalam memahami matematika. Menurut Rosita, bernalar secara matematis merupakan suatu kebiasaan berpikir, dan layaknya suatu kebiasaan, maka penalaran semestinya menjadi bagian yang konsisten dalam setiap pengalaman pengalaman matematis siswa (Rosita, 2014). Sementara menurut Arini \& Rosyidi, indikator kemampuan penalaran meliputi : 1) kemampuan menghubungkan keterkaitan antar unsur-unsur dalam permasalahan; 2) kemampuan mengajukan dugaan (conjectures); 3) kemampuan mengembangkan dan mengevaluasi argument atau pernyataan yang diberikan dalam permasalahan; 4) kemampuan menarik kesimpulan (Arini \& Rosyidi, 2016). Berdasarkan pendapat di atas, maka yang dimaksud dengan kemampuan penalaran Matematika adalah kemampuan menghubungkan, membuat, menyelidiki, menganalisis, dan mengevaluasi ide-ide atau objek-objek Matematika untuk menarik suatu kesimpulan yang benar berdasarkan fakta.

Bernalar merupakan aktivitas mental yang dilakukan secara individu, sementara setiap individu berbeda tergantung tipe kepribadiannya. Setiap individu mempunyai kepribadian yang berbeda-beda dan akan nampak ketika merespon keadaan/lingkungan di sekitarnya dengan cara yang berbeda pula sesuai dengan tipe kepribadian dan tingkat pengetahuan yang dimiliki. Respon ini dapat berupa bahasa, perilaku, perasaan dan pemikiran seseorang (Tarigan, 1987; Jarvis, 2012). Freud dalam Jarvis (2012) mengemukakan pembelahan kepribadian (dissection of the personality) menjadi tiga bagian, yaitu It, I, dan above-I. Tiap-tiap bagian menunjukkan aspek pribadi dan peran yang berbeda dalam pengambilan keputusan. It menggambarkan aspek naluriah dan tidak bermoral dari kepribadian, sudah ada sejak lahir, ingin dipuaskan dan tidak mau penundaan atau ditolak keinginannya dan apabila It tidak mendapatkan kepuasan tersebut, maka akan berdampak pada ketegangan dari diri individu. $I$ adalah aspek pribadi yang juga ada sejak lahir dan menjembatani tuntutan $I t$ maupun dunia luar. I berkembang melalui pengalaman dalam menghadapi sesuatu dalam kehidupan dan 
juga mengembangkan kemampuan untuk berpikir logis (bernalar). Above-I adalah aspek kepribadian yang berisi aturanaturan, yang merupakan aspek moral kepribadian yang menilai baik buruk. Contonya ketika seorang individu haus, sebisa mungkin It mencari apa yang dibutuhkan sebagai pemuas rasa haus, $I$ akan berpikir apakah air yang akan diminum dapat diminum atau tidak dan above-i akan menunjukkan bermacam-macam air yang diperbolehkan diminum dan tidak. Setelah I selesai melakukan proses berpikir sesuai petunjuk above-I maka $I$ akan mengirim informasi hasil berpikir/bernalar kepada It untuk mengambil keputusan apakah akan minum atau tidak (Jarvis, 2012).

Salah satu teori kepribadian dikemukakan oleh Hippocrates dalam Suryabrata (2012) mengemukakan tipe kepribadian atas dasar cairan yang mengalir dalam tubuh manusia terbagi empat tipe yaitu sanguinis, koleris, melankolis, dan, plegmatis (Suryabrata, 2012). Kepribadian sanguinis melihat suatu masalah adalah hal baru yang menarik dan antusias menyelesaikannya dengan cepat, tetapi karena sifat mereka yang moody maka mereka juga akan cepat putus asa dan menyerah jika tidak segera menemukan cara menyelesaikannya. Kepribadian koleris melihat suatu masalah adalah sebuah tantangan yang segera dipecahkan dan sering menemukan pemecahan yang lebih praktis dengan cara mereka sendiri. Kepribadian melankolis melihat suatu masalah dengan sikap pesimis, tetapi mampu menganalisis masalah secara rinci dan memecahkan masalah dengan penuh perhitungan dan kehati-hatian untuk mendapatkan hasil yang sempurna. Kepribadian plegmatis sangat tenang, santai dan tidak tergesa-gesa dalam memecahkan masalah sehingga terkesan malas, tetapi mereka lebih suka tidak mengerjakan apa pun daripada mengerjakan sesuatu dan ternyata itu salah. Keempat kepribadian ini ditemukan oleh peneliti dalam diri mahasiswa. Perbedaan ini menarik perhatian peneliti untuk mengetahui bagaimanakah kemampuan penalaran matematika mahasiswa ditinjau dari tipe kepribadian sanguinis, koleris, melankolis, dan plegmatis. Sehingga hasil penelitian ini menjadi rujukan bagi dosen dalam merancang perkuliahan yang meningkatkan kemampuan penalaran.

\section{Metode}

Penelitian ini menggunakan metode penelitian deskriptif. Fokus penelitian ini adalah bagaimana kemampuan penalaran mahasiswa yang berbeda tipe kepribadiannya dalam memecahkan masalah Matematika. Penelitian ini dilaksanakan dengan tahap-tahap berikut ini:

1. Tahap awal penelitian ini adalah memilih 4 mahasiswa semester IV sebagai subyek penelitian. Subjek penelitian kemudian diberikan tes kepribadian HippocratesGaleneus. Pemilihan subjek penelitian berdasarkan pada hasil tes kepribadian. Berdasarkan hasil tes kepribadian tersebut siswa terbagi menjadi empat kelompok kepribadian, yaitu: sanguinis $(\mathrm{P})$, koleris $(\mathrm{K})$, melankholis $(\mathrm{M})$, dan plegmatis $(\mathrm{P})$. Penetapan subyek adalah siswa dengan skor tertinggi dari tiap kelompoknya. dan apabila tidak ditemukan subjek yang diharapkan maka peneliti akan melakukan tes kepribadian pada kelas lain. Prosedur pemilihan subjek dalam penelitian ini dapat dilihat pada Gambar 1. berikut:

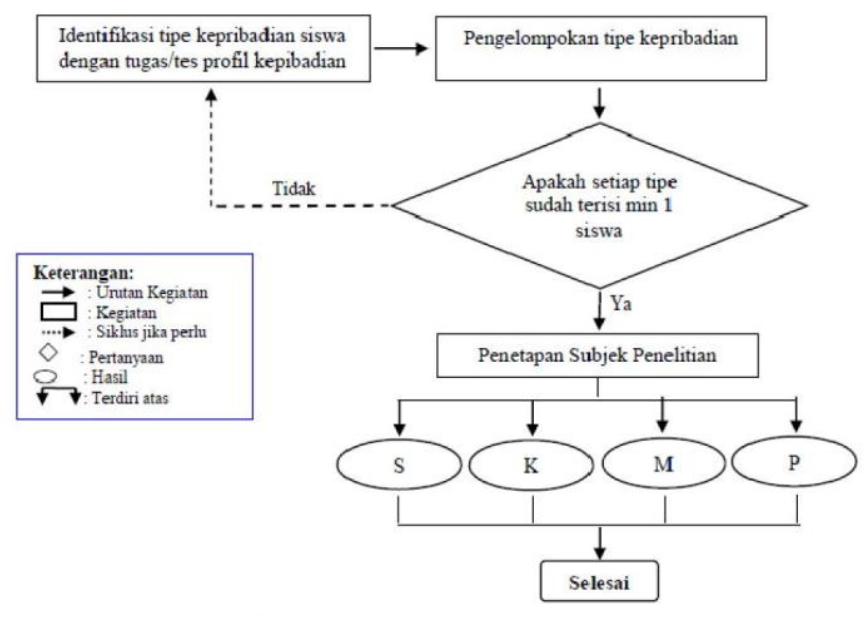

Gambar 1. Alur Pemilihan Subjek Penelitian

2. Untuk memperoleh kemampuan penalaran dari subjek penelitian diberikan tes tertulis memuat butir soal tidak rutin berupa masalah Matematika. Hasil tes tertulis dianalisis berdasarkan langkah-langkah pemecahan masalah yang dikemukakan oleh Polya dengan indikator-indikator kemampuan penalaran. 
Tabel 1. Indikator Kemampuan Penalaran

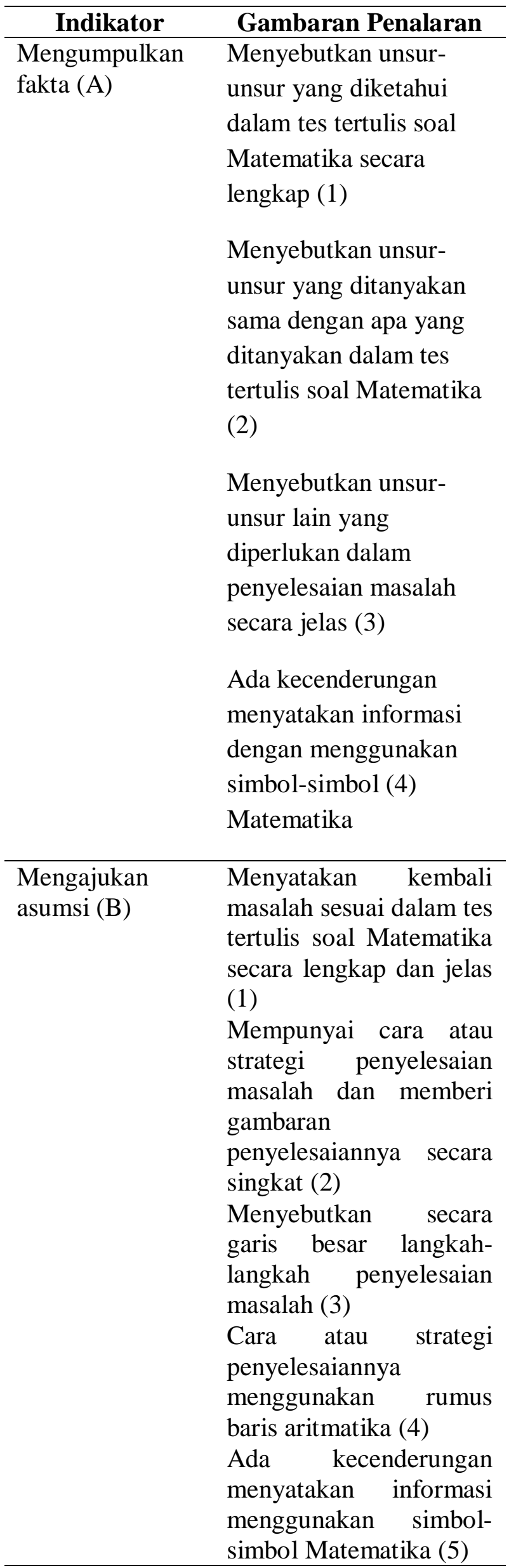

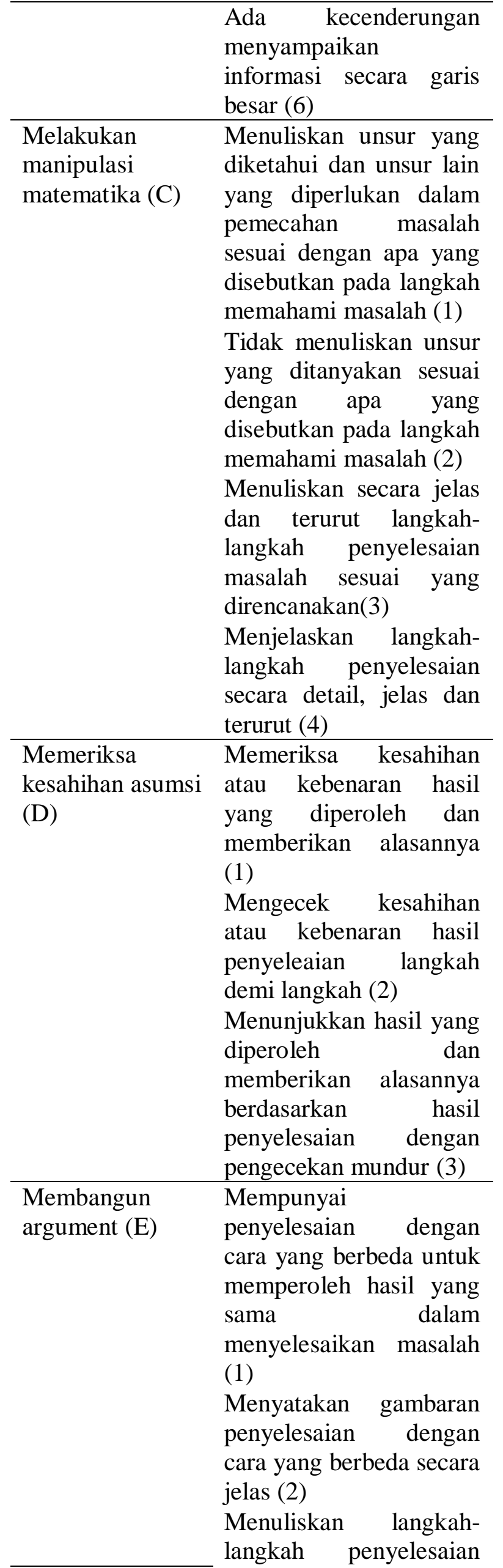


dengan cara yang berbeda secara singkat (3)

Ada kecenderungan memberikan informasi secara singkat dan jelas (4)

\begin{tabular}{ll}
\hline Kemampuan & Membuat kesimpulan \\
membuat & dan memberikan \\
kesimpulan $(\mathrm{F})$ & alasannya berdasarkan \\
& hasil penyelesaian tes \\
& tertulis (1) \\
& Memberikan \\
& penyelesaian dengan \\
& cara yang berbeda dalam \\
& menyelesaikan masalah \\
& (2) kesimpulan \\
& Meyakini hasil \\
& berdasarkan \\
& penyelesaiannya melalui \\
& pengecekan mundur (3) \\
\hline
\end{tabular}

3. Untuk menggali lebih dalam tentang kemampuan penalaran siswa, dilakukan wawancara secara mendalam dengan mengacu pada hasil tes tertulis masalah Matematika. Butir-butir pertanyaan pada pedoman wawancara berdasarkan apa yang akan dicapai dalam proses pemecahan masalah Matematika dengan memperhatikan indikator-indikator kemampuan penalaran.

4. Proses triangulasi data dilakukan dengan menerapkan triangulasi waktu selama 1 pekan melalui metode wawancara.

5. Proses validasi data pada penelitian ini dilakukan dengan menerapkan teknik: a) ketekunan pengamatan; b) pengecekan anggota; c) pemeriksaan sejawat dalam hal ini dosen rekan sejawat; d) kecukupan referensial dalam hal ini perekaman proses wawancara dalam bentuk video kemudian diubah ke dalam transkrip sebagai patokan analisis data dan untuk menguji ketepatan analisis dan penafsiran data.

6. Tes tertulis berupa masalah yang dianalisis adalah masalah baris dan deret aritmatika. Masalah Baris Aritmatika (BA) terdiri dari dua soal yaitu M1 dan M3, begitu juga masalah Deret Aritmatika (DA) terdiri dari dua soal yaitu M2 dan M4. Data-data yang telah diperoleh melalui hasil penyelesaian tes tertulis dan hasil wawancara dari subjek penelitian. Jenis analisis data yang digunakan adalah analisis data "Model Miles dan Huberman"

\section{Hasil dan Pembahasan}

\section{A. Deskripsi Tipe Kepribadian Mahasiswa}

Langkah awal di dalam penelitian ini adalah menentukan subjek penelitian. Subjek penelitian dipilih satu orang untuk setiap kelompok tipe kepribadian. Instrumen yang digunakan untuk mengidentifikasi tipe kepribadian siswa diadapatasi dari buku Personality Plus karangan Florence Littauer (1996). Hasil identifikasi tipe kepribadian mahasiswa dapat dilihat pada Tabel 2 . sebagai berikut.

Tabel 2. Hasil Identifikasi Tipe

Kepribadian Mahaiswa Program Studi Pendidikan Matematika

\begin{tabular}{clcc}
\hline No & $\begin{array}{c}\text { Tipe } \\
\text { Kepribadian }\end{array}$ & Jumlah & $\begin{array}{c}\text { Persentase } \\
(\%)\end{array}$ \\
\hline 1 & Sanguinis (S) & 2 & 6,67 \\
2 & Koleris (K) & 1 & 3,33 \\
3 & $\begin{array}{l}\text { Melankolis } \\
(\mathrm{M})\end{array}$ & 4 & 13,33 \\
4 & Plegmatis (P) & 11 & 36,67 \\
5 & $\begin{array}{l}\text { Melankolis } \\
\text { (M) dan }\end{array}$ & 1 & 3,33 \\
& $\begin{array}{l}\text { Plegmatis (P) } \\
\text { Tidak }\end{array}$ & & \\
& $\begin{array}{l}\text { mendominasi } \\
\text { tipe }\end{array}$ & 11 & 36,67 \\
& $\begin{array}{l}\text { kepribadian } \\
\text { Jumlah }\end{array}$ & & \\
\hline
\end{tabular}

Tabel 1 menunjukkan bahwa terdapat mahasiswa yang memiliki tipe kepribadian lebih dari satu. Terdapat satu mahasiswa yang memiliki campuran tipe kepribadian antara kepribadian melankolis (M) dan kepribadian plegmatis (P). Artinya, mahasiswa tersebut memiliki hasil skor tertinggi untuk kepribadian melankolis (M) dan kepribadian plegmatis (P). Mahasiswa dengan tipe seperti ini memiliki perpaduan sifat antara kepribadian melankolis (M) dan kepribadian plegmatis (P). Perpaduan tipe kepribadian disebut tipe campuran alami. Keduanya sama introvert, pesimis, dan bicara lemah lembut. Mereka serius dan tidak suka menjad pusat perhatian tetapi mereka 
biasanya kesulitan dalam membuat keputusan karena sifat kedua tipe ini adalah cenderung lamban, suka menundanunda, dan sering tampak tertekan jika keinginannya tidak sesuai dengan harapan.

Pada penelitian ini, mahasiswa yang menjadi subjek penelitian adalah mahasiswa yang dominan pada satu tipe kepribadian, artinya mahasiswa yang memiliki skor tertinggi pada setiap kelompok tipe kepribadiannya.

Berikut ini merupakan hasil temuan peneliti berdasarkan hasil analisis penyelesaian masalah BA dan DA pada masing-masing subjek.

\section{Persamaan dan Perbedaan Penalaran Sanguinis (S) pada Penyelesaian Masalah BA dan DA}

\section{Persamaan}

1. Pada Indikator mengumpulkan fakta, $S$ menyebutkan unsur-unsur yang diketahui, unsur-unsur lain yang diperlukan dan yang ditanyakan dalam tes tertulis soal Matematika. Ada kecenderungan $\mathrm{S}$ dalam menyampaikan informasi menggunakan simbol-simbol Matematika.

2. Pada indikator mengajukan asumsi, $\mathbf{S}$ menyatakan kembali masalah secara lengkap dan jelas. $\mathrm{S}$ mempunyai cara atau strategi penyelesaian masalah menggunakan rumus baris aritmatika. $S$ memberikan gambaran singkat penyelesaian dengan simbol-simbol Matematika dan menyebutkan langkah-langkah penyelesaian pada kedua jenis masalah dan ada kecenderungan $\mathrm{S}$ menyampaikan informasi secara garis besar tetapi singkat dan jelas

3. Pada indikator melakukan manipulasi Matematika, $S$ menuliskan unsur yang diketahui dan unsur lain yang diperlukan dalam pemecahan masalah sesuai dengan apa yang disebutkan pada langkah memahami masalah tetapi tidak menuliskan unsur yang ditanyakan. Selanjutnya, S menyelesaikan masalah sesuai dengan yang direncanakan secara jelas dan terurut serta menjelaskan langkaglangkah penyelesaian secara detail jelas dan terurut.

4. Pada indikator memeriksa kesahihan asumsi, $\mathrm{S}$ memeriksa hasil yang diperoleh dan memberikan alasannya kebenarannya berdasarkan hasil penyelesaian dengan mengecek langkah demi langkah.

5. Pada indikator membangun argumen, $\mathrm{S}$ mempunyai penyelesaian dengan cara berbeda untuk memperoleh hasil yang sama dan menuliskan langkah-langkah penyelesaiannya secaraa singkat dan jelas.

6. Pada langkah membuat kesimpulan, $\mathrm{S}$ menarik kesimpulan berdasarkan hasil penyelesaian. S mempunyai argumen yang mendukung (penyelesaian dengan cara yang berbeda) di dalam menarik kesimpulan. S meyakini hasil yang diperoleh berdasarkan hasil penyelesaian melalui pengecekan mundur.

\section{Perbedaan}

1. Pada indikator mengumpulkan fakta pada masalah jenis pertama (BA), $\mathrm{S}$ menyebutkan unsur-unsur yang diketahui secara lengkap. Pada masalah jenis kedua (DA), S menyebutkan unsurunsur yang diketahui secara tidak lengkap untuk M2 tetapi menyebutkan secara lengkap untuk M4. Sehingga, ada kecenderungan $\mathrm{S}$ menyebutkan unsurunsur yang diketahui secara lengkap.

2. Pada indikator memeriksa kesahihan asumsi pada masalah pertama (BA), S memberikan alasan untuk mendapatkan hasil penyelesaian masalah. Pada masalah jenis kedua (DA), $\mathrm{S}$ memberikan alasan untuk mendapatkan hasil penyelesaian masalah M2 tetapi tidak memberikan alasannya untuk M4. Sehingga, ada kecenderungan $\mathrm{S}$ mampu memberikan alasan untuk mendapatkan hasil penyelesaian masalah.

Berdasarkan persamaan dan perbedaan penalaran S pada masalah BA dan DA diatas, maka dapat ditarik kesimpulan gambaran penalaran $\mathrm{S}$ dalam memecahkan masalah Matematika. Gambaran ini, dapat dilihat pada Tabel 3. sebagai berikut. 
Tabel 3. Gambaran Penalaran S dalam Memecahkan Masalah Matematika

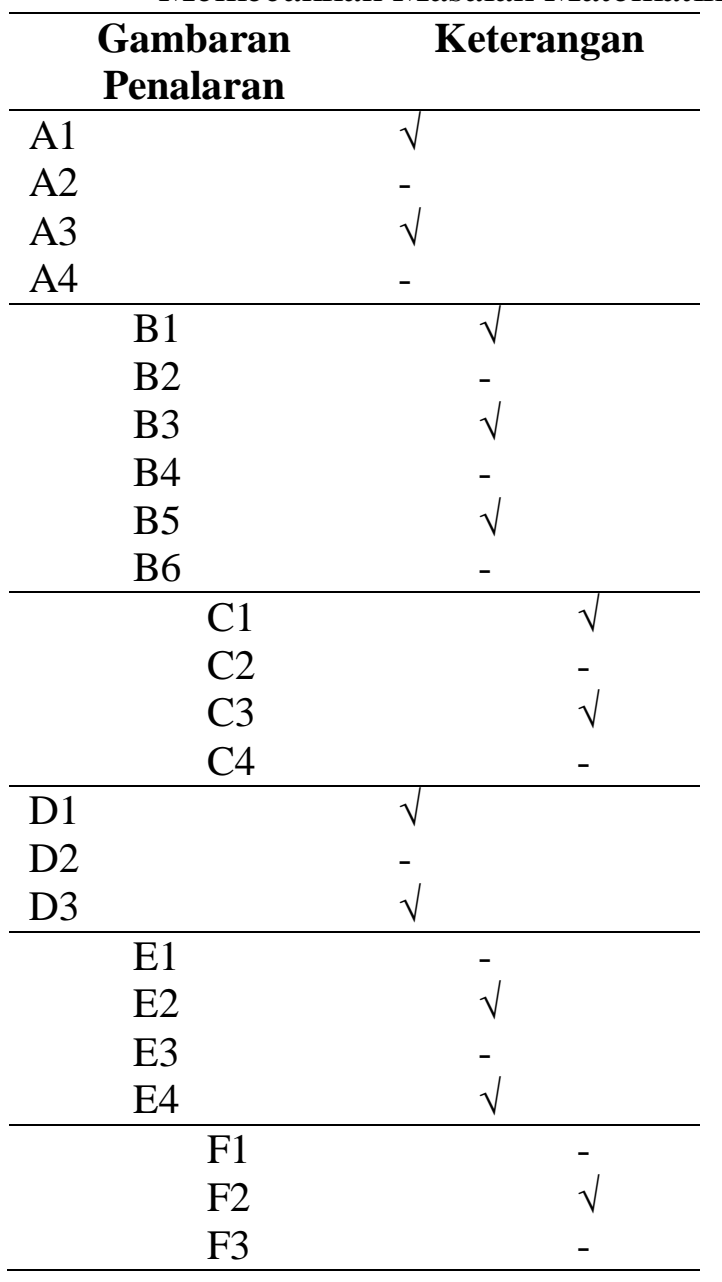

Mahasiswa yang memiliki tipe kepribadian sanguinis yang disimbolkan S, setelah membaca tes tertulis soal Matematika dan ditanya apa memahami masalah yang diberikan maka secara spontan $\mathrm{S}$ melihat soal tersebut dan membacanya kembali.

Ada kecenderungan $\mathrm{S}$ menggunakan simbol-simbol Matematika. Hal ini dapat dilihat pada saat $\mathrm{S}$ ditanyakan unsur-unsur dalam soal, meskipun $\mathrm{S}$ melihat teks soal tetapi $\mathrm{S}$ tidak menjelaskan masalah secara utuh, ia lebih memanfaatkan simbol Matematika sebagai usaha mempresentasikan jawaban pertanyaan tanpa menjelaskan makna dari simbol tersebut. Terbukti pada semua jenis pertanyaan dan memberikan gambaran penyelesaian mahasiswa ini menggunakan simbol Matematika.

S mempunyai lebih dari satu cara pada setiap masalah yang diberikan. Ini menunjukkan bahwa $S$ mempunyai ide kreatif dalam memecahkan masalah.
Kemudian, $\mathrm{S}$ menyatakan gambaran dan menyebutkan langkah-langkah penyelesaian masalah. Meskipun $S$ menyampaikan informasi secara garis besar tetapi $\mathrm{S}$ mampu memberikan informasi dengan lengkap, jelas dan terurut. Selanjutnya, fakta yang ditulis sesuai dengan yang disebutkan pada saat wawancara tetapi ia tidak menuliskan unsur yang ditanyakan. S menyelesaikan masalah sesuai dengan yang rencanakan.

Setelah S menyelesaikan masalah maka $\mathrm{S}$ memeriksa kembali hasil penyelesaian tertulisnya. Mahasiswa $\mathrm{S}$ membuat kesimpulan berdasarkan pertanyaan yang diajukan dalam tes tertulis. Kesimpulan yang dibuat sesuai dengan hasil penyelesaian tertulisnya. Kemudian, $\mathrm{S}$ mempunyai penyelesaian dengan cara yang berbeda yang dapat mendukung penyelesaian pertamanya, artinya mempunyai lebih dari satu penyelesaian. S meyakini hasil kesimpulan berdasarkan hasil penyelesaian tes tertulis dengan pengecekan mundur.

\section{Persamaan dan Perbedaan Penalaran Koleris (K) pada Penyelesaian Masalah BA dan DA}

\section{Persamaan}

1. Pada Indikator mengumpulkan fakta, $K$ menyebutkan unsur-unsur yang diketahui dan unsur yang ditanyakan sama dengan apa yang diajukan dalam tes tertulis soal Matematika tetapi tidak menyebutkan unsur-unsur lain yang diperlukan dalam pemecahan masalah. Ada kecenderungan $\mathrm{K}$ menyatakan informasi berdasarkan konteks tes tertulis

2. Pada indikator mengajukan asumsi, $\mathrm{K}$ menyatakan kembali masalah secara lengkap dan jelas, mempunyai cara atau strategi untuk menyelesaikan masalah dengan menggunakan rumus Baris dan Deret Aritmatika tetapi tidak memberi gambaran penyelesaiannya. $\mathrm{K}$ cenderung menyebutkan secara garis besar langkah-langkah penyelesaiannya.

3. Pada indikator melakukan manipulasi Matematika, K tidak menuliskan unsur yang diketahui, unsur yang ditanyakan dan unsur lain dalam penyelesaian masalah sesuai dengan yang disebutkan pada langkah memahami masalah. K 
menuliskan secara singkat dan terurut penyelesaian dan menjelaskan langkah-langkah penyelesaian masalah secara detail, singkat dan terurut. Selanjutnya, K menyelesaikan masalah sesuai dengan yang direncanakan.

4. Pada indikator memeriksa kesahihan asumsi, $\mathrm{K}$ menunjukkan atau memeriksa hasil yang diperoleh dan memberikan alasannya, $\mathrm{K}$ mengecek kebenarannya langkah demi langkah. Ada kecenderungan $\mathrm{K}$ memeriksa kesahihan atau kebenaran hasil penyelesaian berdasarkan hasil tes tertulis soal Matematika.

5. Pada indikator membangun argumen, $\mathrm{K}$ mempunyai penyelesaian dengan cara yang berbeda untuk memperoleh hasil yang sama. Selanjutnya, K menyatakan gambaran dengan jelas penyelesaian yang berbeda tersebut dan menuliskan langkah-langkahnya dengan singkat. $\mathrm{K}$ memberikan informasi tertulis secara jelas dan singkat. Ada kecenderungan $\mathrm{K}$ memanfaatkan pengalaman untuk menyeleaikan masalah yang sama.

6. Pada langkah membuat kesimpulan, $\mathrm{K}$ menarik kesimpulan berdasarkan pertanyaan yang diajukan dalam tes tertulis soal Matematika. K mempunyai argumen yang mendukung (cara yang berbeda untuk memperoleh hasil yang sama) di dalam menyelesaikan masalah. $\mathrm{K}$ meyakini hasil yang diperoleh berdasarkan hasil penyelesaian tes tertulis soal Matematika.

\section{Perbedaan}

1. Pada indikator mengumpulkan fakta pada masalah jenis pertama (BA), $\mathrm{K}$ menyebutkan unsur-unsur yang diketahui secara tidak lengkap untuk M1 dan menyebutkan secara lengkap untuk M3. Pada masalah jenis kedua jenis kedua (DA), $\mathrm{K}$ menyebutkan unsur-unsur yang diketahui secara tidak lengkap. Sehingga, ada kecenderungan $\mathrm{K}$ menyebutkan unsur-unsur yang diketahui secara tidak lengkap.
2. Pada indikator mengajukan asumsi pada masalah jenis pertama (BA), $\mathrm{K}$ menggunakan cara yang berbeda untuk menyelesaikan masalah untuk M1 dan menggunakan rumus untuk untuk M3. Pada masalah jenis kedua (DA), K menggunakan rumus dalam menyelesaikan masalah. Sehingga ada kecenderungan $\mathrm{K}$ menggunakan rumus dalam menyelesaikan masalah.

3. Pada indikator mengajukan asumsi pada jenis pertama (BA), $\mathrm{K}$ tidak memberikan gambaran penyelesaian masalah. Pada masalah jenis kedua (DA), $\mathrm{K}$ memberikan gambaran penyelesaian masalah untuk M2 tetapi tidak memberikan gambarannya untuk M4. Sehingga ada kecenderungan K tidak memberikan gambaran penyelesaian masalah.

4. Pada indikator mengajukan asumsi pada jenis pertama (BA), K menyebutkan secara tidak terurut langkah-langkah penyelesaian masalah untuk M1 dan menyebutkan secara terurut untuk M3. Pada masalah jenis kedua (DA), menyebutkan secara berurut langkah-langkah penyelesaian masalah. Sehingga ada kecenderungan $\mathrm{K}$ menyebutkan secara terurut langkahlangkah penyelesaian masalah.

5. Pada indikator melakukan manipulasi Matematika, pada masalah jenis pertama (BA), $\mathrm{K}$ menulis langkahlangkah penyelesaian secara tidak terurut untuk M1 tetapi ditulis secara terurut untuk M3. Pada masalah jenis kedua (DA), $\mathrm{K}$ menulis langkahlangkah penyelesaian secara terurut. Sehingga ada kecenderungan $K$ menuliskan langkah-langkah penyelesaian secara terurut.

6. Pada indikator kemampuan memeriksa kesahihan asumsi, pada masalah jenis pertama (BA), $\mathrm{K}$ memberikan alasan kebenaran hasil yang diperoleh berdasarkan hasil penyelesaian tes tertulis. Pada masalah jenis kedua (DA), K memberikan alasan kebenaran hasil yang diperoleh berdasarkan hasil penyelesaian tes tertulis untuk M2 tetapi memberikan alasannya berdasarkan pertanyaan yang diajukan untuk M4. Sehingga ada 
kecenderungan $\mathrm{K}$ memberikan alasan kebenaran hasil yang diperoleh berdasarkan hasil penyelesaian tes tertulis.

7. Pada indikator membangun argumen pada masalah jenis pertama (BA), $\mathrm{K}$ tidak mempunyai penyelesaian yang berbeda untuk M1 tetapi mempunyai penyelesaian yang berbeda untuk M3. Pada masalah jenis kedua (DA), $\mathrm{K}$ mempunyai penyelesaian yang berbeda. Sehingga ada kecenderungan $\mathrm{K}$ mempunyai penyelesaian yang berbeda untuk memperoleh hasil yang sama.

Berdasarkan persamaan dan perbedaan penalaran $\mathrm{K}$ pada masalah BA dan DA diatas, maka dapat ditarik kesimpulan gambaran penalaran $\mathrm{K}$ dalam memecahkan masalah Matematika dapat dilihat pada Tabel 4. sebagai berikut:

Tabel 4. Gambaran Penalaran K dalam Memecahkan Masalah Matematika

\begin{tabular}{|c|c|c|c|}
\hline \multicolumn{2}{|c|}{$\begin{array}{l}\text { Gambaran } \\
\text { Penalaran }\end{array}$} & \multicolumn{2}{|c|}{ Keterangan } \\
\hline A1 & & $\sqrt{ }$ & \\
\hline $\mathrm{A} 2$ & & - & \\
\hline A3 & & $\sqrt{ }$ & \\
\hline A4 & & - & \\
\hline & & & $\sqrt{ }$ \\
\hline & & & - \\
\hline & & & $\sqrt{ }$ \\
\hline & & & - \\
\hline & & & $\sqrt{ }$ \\
\hline & & & - \\
\hline & $\mathrm{C} 1$ & & $\sqrt{ }$ \\
\hline & $\mathrm{C} 2$ & & - \\
\hline & C3 & & $\sqrt{ }$ \\
\hline & C4 & & - \\
\hline D1 & & & \\
\hline D2 & & $\sqrt{ }$ & \\
\hline D3 & & - & \\
\hline & & & $\sqrt{ }$ \\
\hline & & & - \\
\hline & & & $\sqrt{ }$ \\
\hline & & & - \\
\hline & F1 & & $\sqrt{ }$ \\
\hline & $\mathrm{F} 2$ & & - \\
\hline & F3 & & $\sqrt{ }$ \\
\hline
\end{tabular}

Mahasiswa yang memiliki tipe kepribadian koleris yang disimbolkan $\mathrm{K}$, setelah membaca soal Matematika dan ditanya apakah memahami masalah yang diberikan, $\mathrm{K}$ tidak membaca kembali soal Matematika tersebut. Pada saat ditanya unsur-unsur dalam soal, $\mathrm{K}$ menyebutkan unsur-unsur yang diketahui dan unsur yang ditanyakan secara tidak lengkap dan jawaban yang diberikan singkat dan langsung pada inti dari pertanyaan. $\mathrm{K}$ tidak menyebutkan unsur lain yang diperlukan dalam penyelesaian.

Mahasiswa K mempunyai lebih dari satu cara untuk menyelesaikan masalah. K tidak memberi gambaran penyelesaian tetapi langsung menyebutkan langkah-langkah penyelesaian masalah secara garis besarnya saja secara singkat. Selanjutnya, K juga tidak menuliskan fakta yang ada dalam tes tertulis Matematika. Ada kecenderungan K memanfaatkan pengalaman untuk menyelesaikan masalah yang sama. Pada saat pengambilan data pertama $\mathrm{K}$ hanya memiliki satu cara penyelesaian tetapi pada pengambilan data ketiga (triangulasi), $\mathrm{K}$ memilki dua cara penyelesaian untuk memperoleh hasil yang sama dan mengerjakannya. Pada saat menyelesaikan masalah $\mathrm{K}$ menyelesaikan masalah sesuai dengan yang rencanakan.

Mahasiswa $\mathrm{K}$ membuat kesimpulan berdasarkan pertanyaan yang diajukan dalam tes tertulis. Kesimpulan yang dibuat sesuai dengan hasil penyelesaian tertulisnya. Kemudian, $\mathrm{K}$ mempunyai penyelesaian dengan cara yang berbeda yang dapat mendukung penyelesaian pertamanya, artinya mempunyai lebih dari satu penyelesaian. $\mathrm{K}$ meyakini hasil kesimpulan berdasarkan hasil penyelesaian tes tertulis dengan pengecekan mundur.

\section{Persamaan dan Perbedaan Penalaran Melankolis (M) pada Penyelesaian Masalah BA dan DA}

\section{Persamaan}

1. Pada Indikator mengumpulkan fakta, $\mathbf{M}$ menyebutkan unsur-unsur yang diketahui dan unsur yang ditanyakan tetapi tidak menyebutkan unsur-unsur lain yang diperlukan dalam pemecahan masalah. Ada kecenderungan $\mathrm{M}$ menyatakan informasi berdasarkan konteks tes tertulis

2. Pada indikator mengajukan asumsi, $\mathbf{M}$ menyatakan kembali masalah secara 
lengkap dan jelas, mempunyai cara atau strategi untuk menyelesaikan masalah dan memberi gambaran penyelesaiannya secara jelas. $\mathrm{M}$ menggunakan cara yang berbeda untuk menyelesaikan masalah. $\mathrm{M}$ cenderung menyatakan gambaran dan langkah-langkah penyelesaian dengan cara menghitung pada kedua jenis masalah yang diberikan.

3. Pada indikator melakukan manipulasi Matematika, $M$ menuliskan unsur yang diketahui dan unsur yang ditanyakan sesuai dengan apa yang disebutkan pada langkah memahami masalah. M menuliskan penyelesaian masalah secara jelas dan terurut, $M$ juga menjelaskan langkah-langkah penyelesaiannya secara detail, jelas dan terurut. Selanjutnya, $\mathbf{M}$ menyelesaikan masalah sesuai dengan yang direncanakan.

4. Pada indikator memeriksa kesahihan asumsi, M menunjukkan atau memeriksa hasil yang diperoleh dan memberikan alasannya, $M$ mengecek kebenarannya langkah demi langkah. Ada kecenderungan $M$ memeriksa kesahihan atau kebenaran hasil yang diperoleh berdasarkan hasil penyelesaian tes tertulisnya.

5. Pada indikator membangun argumen, M mempunyai penyelesaian dengan cara yang berbeda untuk memperoleh hasil yang sama. $M$ tidak memberikan gambaran maupun menuliskan langkah-langkah penyelesaiannya. Ada kecenderungan $M$ tidak memanfaatkan pengalaman untuk menyelesaikan masalah yang sama.

6. Pada langkah membuat kesimpulan, $\mathbf{M}$ menarik kesimpulan berdasarkan hasil penyelesaian tes tertulis soal Matematika. M meyakini hasil pekerjaannya melalui hasil tes tertulis soal Matematika.

\section{Perbedaan}

1. Pada indikator mengajukan asumsi pada masalah jenis pertama (BA), M menyebutkan langkah-langkah penyelesaian secara tidak terurut untuk M1 dan menyebutkan secara terurut untuk M3. Pada masalah jenis kedua (DA), M menyebutkan langkahlangkah penyelesaian secara terurut. Sehingga ada kecenderungan $M$ menyebutkan langkah-langkah penyelesaian secara terurut dan kadang tidak terurut tergantung dari bentuk masalah yang dipahami.

2. Pada indikator melakukan manipulasi Matematika, pada masalah jenis pertama (BA), M tidak menyebutkan unsur yang diperlukan dalam penyelesaian masalah. Pada masalah jenis kedua (DA), M menyebutkan unsur yang diperlukan dalam penyelesaian masalah untuk M2 dan tidak menyebutkan unsur yang diperlukan untuk M4. Sehingga ada kecenderungan $\mathrm{M}$ tidak menyebutkan unsur yang diperlukan dalam penyelesaian masalah.

3. Pada indikator melakukan manipulasi Matematika, pada masalah jenis pertama (BA), M menulis penyelesaian masalah secara tidak terurut untuk M1 dan secara terurut untuk M3. Pada masalah jenis kedua (DA), M menulis penyelesaian masalah secara terurut. Sehingga ada kecenderungan $\mathrm{M}$ menulis penyelesaian masalah secara terurut.

4. Pada indikator kemampuan memeriksa kesahihan asumsi, pada masalah jenis pertama (BA), M memberikan alasan kebenaran hasil tes tertulis yang diperoleh berdasarkan pertanyaan yang diajukan pada tes tertulis untuk M1 dan berdasarkan hasil penyelesaian untuk M3. Pada masalah jenis kedua (DA), M tidak memberikan alasan kebenaran hasil yang diperoleh untuk M2 dan memberikan alasan kebenaran hasil yang diperoleh berdasarkan hasil penyelesaian tes tertulis untuk M4. Sehingga ada kecenderungan $\mathrm{M}$ memberikan alasan kebenaran hasil yang diperoleh berdasarkan hasil penyelesaian tes tertulis.

Berdasarkan persamaan dan perbedaan penalaran $\mathrm{M}$ pada masalah BA dan DA diatas, maka dapat ditarik kesimpulan gambaran penalaran $\mathrm{M}$ dalam memecahkan masalah Matematika dapat dilihat pada Tabel 5. sebagai berikut.

Tabel 5. Gambaran Penalaran M dalam 
Memecahkan Masalah Matematika

\begin{tabular}{|c|c|c|c|}
\hline \multicolumn{2}{|c|}{$\begin{array}{l}\text { Gambaran } \\
\text { Penalaran }\end{array}$} & \multicolumn{2}{|c|}{ Keterangan } \\
\hline A1 & & $\sqrt{ }$ & \\
\hline $\mathrm{A} 2$ & & - & \\
\hline A3 & & $\sqrt{ }$ & \\
\hline A4 & & - & \\
\hline & & & \\
\hline & & & \\
\hline & & & \\
\hline & & & \\
\hline & & & \\
\hline & & & \\
\hline & $\mathrm{C} 1$ & & $\sqrt{ }$ \\
\hline & $\mathrm{C} 2$ & & - \\
\hline & $\mathrm{C} 3$ & & $\sqrt{ }$ \\
\hline & $\mathrm{C} 4$ & & - \\
\hline D1 & & - & \\
\hline $\mathrm{D} 2$ & & $\sqrt{ }$ & \\
\hline D3 & & - & \\
\hline & & & \\
\hline & & & \\
\hline & & & \\
\hline & & & \\
\hline & $\mathrm{F} 1$ & & $\sqrt{ }$ \\
\hline & $\mathrm{F} 2$ & & - \\
\hline & $\mathrm{F} 3$ & & $\sqrt{ }$ \\
\hline
\end{tabular}

Mahasiswa yang memiliki tipe kepribadian melankolis yang disimbolkan M, setelah membaca tes tertulis soal Matematika dan ditanya apa yang dia memahami masalah yang diberikan maka M sekali-kali melihat tes tertulis soal Matematika dari bagian ke bagian tes. Informasi yang diberikan sama dengan soal yang diajukan secara lengkap dan jelas. Meskipun M melihat soal tetapi tidak menyebutkan unsur-unsur lain yang diperlukan dalam penyelesaian masalah Matematika.

Mahasiswa $\mathrm{M}$ mempunyai satu cara untuk menyelesaikan masalah. Kemudian, M menyatakan gambaran dan menyebutkan langkah-langkah penyelesaian masalah dengan jelas dan terurut. Ada kecenderungan $\mathrm{M}$ menyampaikan dengan mengitung unsurunsur yang ada dalam soal Matematika. Pada setiap masalah yang diajukan, $M$ memberikan penjelasan gambaran dan langkah-langkah penyelesaian masalah mulai dari awal sampai akhir selalu menggunakan angka-angka yang ada dalam soal Matematika sambil menuliskan penyelesaiannya seolah-olah sedang menyelesaikan masalah meskipun belum sampai pada tahap menemukan hasilnya. Ini menunjukkan bahwa $M$ dalam menyampaikan informasi cenderung memerinci masalah dalam bentuk tulisan.

Selanjutnya, fakta yang ditulis sesuai dengan apa yang disebutkan pada saat wawancara tetapi ia tidak menuliskan unsur lain yang diperlukan dalam penyelesain masalah. Pada saat menyelesaikan masalah M menyelesaikan masalah sesuai dengan yang rencanakan.

Mahasiswa M membuat kesimpulan berdasarkan hasil penyelesaiannya. Kesimpulan yang dibuat sesuai dengan hasil penyelesaian tertulisnya. Kemudian, M tidak mempunyai penyelesaian dengan cara yang berbeda yang dapat mendukung penyelesaian pertamanya, artinya hanya mempunyai satu penyelesaian. M meyakini hasil kesimpulan berdasarkan hasil penyelesaian tes tertulisnya.

\section{Persamaan dan Perbedaan Penalaran Melankolis (P) pada Penyelesaian Masalah BA dan DA}

\section{Persamaan}

1. Pada indikator mengumpulkan fakta, $\mathrm{P}$ menyebutkan unsur-unsur yang diketahui, unsur-unsur ditanyakan dan unsur-unsur lain yang diperlukan dalam penyelesaian masalah secara lengkap dan jelas. Ada kecenderungan $\mathrm{P}$ dalam menyatakan informasi menggunakan simbol-simbol Matematika.

2. Pada indikator mengajukan asumsi, $P$ menyatakan kembali masalah secara lengkap dan jelas. $\mathrm{P}$ mempunyai cara atau strategi untuk menyelesaikan masalah dan memberi gambaran penyelesaiannya secara jelas. Selanjutnya, $\mathrm{P}$ menyebutkan secara terurut langkah-langkah penyelesaian masalah. Ada kecenderungan $P$ menyampaikan informasi secara jelas dan terurut.

3. Pada indikator melakukan manipulasi Matematika, $\mathrm{P}$ menuliskan unsur yang diketahui dan unsur yang ditanyakan sesuai dengan apa yang disebutkan pada langkah memahami masalah. $\mathrm{P}$ menuliskan cara atau strategi penyelesaian masalah secara jelas, 
terurut dan terperinci. $P$ juga menjelaskan secara detail, jelas, terurut dan terperinci langkah-langkah penyelesaian masalah. Selanjutnya, $\mathrm{P}$ menyelesaikan masalah sesuai dengan yang direncanakan.

4. Pada indikator memeriksa kesahihan asumsi, $\mathrm{P}$ memeriksa hasil yang diperoleh dan memberikan alasannya, $\mathrm{P}$ mengecek kebenarannya langkah demi langkah. Ada kecenderungan $\mathrm{P}$ memeriksa kesahihan atau kebenaran hasil yang diperoleh dan alasannnya berdasarkan hasil penyelesaian tes tertulis soal Matematika.

5. Pada indikator membangun argumen yang mendukung, $\mathrm{P}$ mempunyai penyelesaian dengan cara yang berbeda untuk memperoleh hasil yang sama dan menyatakan gambaran penyelesaiannya secara detail. $\mathrm{P}$ memberikan informasi tertulis secara terperinci. Ada kecenderungan $P$ memanfaatkan pengalaman untuk menyeleaikan masalah yang sama. Ada kecenderungan $\mathrm{P}$ menyatakan informasi dalam bentuk gambar atau diagram.

6. Pada langkah membuat kesimpulan, $\mathbf{P}$ menarik kesimpulan berdasarkan hasil penyelesaian tes tertulis soal Matematika. $\mathrm{P}$ mempunyai argumen yang mendukung (penyelesaian dengan cara yang berbeda) untuk menyelesaikan masalah. $\mathrm{P}$ meyakini hasil pekerjaannya berdasarkan hasil penyelesaian tes tertulis soal Matematika.

\section{Perbedaan}

1. Pada Indikator mengumpulkan fakta pada masalah jenis pertama (BA), $\mathrm{P}$ menyebutkan unsur-unsur yang diketahui secara lengkap dan jelas. Pada masalah jenis kedua (DA), $\mathrm{P}$ menyebutkan unsur-unsur yang diketahui secara lengkap untuk M2 dan menyebutkan secara lengkap dan jelas untuk M4. Sehingga ada kecenderungan $\mathrm{P}$ menyebutkan unsurunsur yang diketahui secara lengkap dan jelas.

2. Pada indikator melakukan manipulasi Matematika, pada masalah jenis pertama (BA), $\mathrm{P}$ tidak menulis unsur yang diperlukan dalam penyelesaian masalah untuk M1 tetapi menuliskan unsur yang diperlukan untuk M3. Pada masalah jenis kedua (DA), $P$ tidak menulis unsur yang diperlukan dalam penyelesaian masalah. Sehingga ada kecenderungan $\mathrm{P}$ tidak menuliskan unsur yang diperlukan dalam penyelesaian masalah.

3. Pada indikator membuat argumen, pada masalah jenis pertama (BA), P mempunyai penyelesaian dengan cara yang berbeda. Pada masalah jenis kedua (DA), P tidak mempunyai penyelesaian dengan cara yang berbeda untuk M2 dan mempunyai penyelesaian untuk M4. Sehingga ada kecenderungan $\mathrm{P}$ mempunyai penyelesaian dengan cara yang berbeda untuk memperoleh hasil yang sama.

Berdasarkan persamaan dan perbedaan penalaran $\mathrm{P}$ pada masalah BA dan DA diatas, maka dapat ditarik kesimpulan gambaran penalaran $\mathrm{P}$ dalam memecahkan masalah Matematika dapat dilihat pada Tabel 6. sebagai berikut:

Tabel 6. Gambaran Penalaran P dalam Memecahkan Masalah Matematika

\begin{tabular}{|c|c|c|c|}
\hline \multicolumn{2}{|c|}{$\begin{array}{l}\text { Gambaran } \\
\text { Penalaran } \\
\end{array}$} & \multicolumn{2}{|c|}{ Keterangan } \\
\hline A1 & & $\sqrt{ }$ & \\
\hline $\mathrm{A} 2$ & & - & \\
\hline A3 & & $\sqrt{ }$ & \\
\hline A4 & & - & \\
\hline & B1 & & $\sqrt{ }$ \\
\hline & B2 & & - \\
\hline & B3 & & $\sqrt{ }$ \\
\hline & B4 & & - \\
\hline & B5 & & $\sqrt{ }$ \\
\hline & B6 & & - \\
\hline & $\mathrm{C} 1$ & & $\sqrt{ }$ \\
\hline & $\mathrm{C} 2$ & & - \\
\hline & $\mathrm{C} 3$ & & $\sqrt{ }$ \\
\hline & $\mathrm{C} 4$ & & - \\
\hline D1 & & - & \\
\hline D2 & & $\sqrt{ }$ & \\
\hline D3 & & - & \\
\hline & E1 & & - \\
\hline & E2 & & $\sqrt{ }$ \\
\hline & E3 & & - \\
\hline & E4 & & $\sqrt{ }$ \\
\hline
\end{tabular}




\begin{tabular}{ll}
\hline F1 & - \\
F2 & $\sqrt{ }$ \\
F3 & - \\
\hline
\end{tabular}

Mahasiswa yang memiliki tipe kepribadian plegmatis yang disimbolkan $\mathrm{P}$, setelah membaca soal Matematika dan ditanya unsur-unsur dalam soal Matematika maka dengan tenang $P$ menyebutkan secara lengkap dan jelas. Meskipun $\mathrm{P}$ juga sesekali melihat soal Matematika tetapi $\mathrm{P}$ menjawab setiap pertanyaan dengan merangkai kalimatnya sendiri. Ada kecenderngan P menggunakan simbol-simbol Matematika yang diikuti makna dari simbol tersebut.

Mahasiswa $\mathrm{P}$ mempunyai lebih dari satu cara untuk menyelesaikan masalah. Ada kecenderungan $\mathrm{P}$ memanfaatkan pengalaman untuk menyelesaikan masalah yang sama. Pada saat pengambilan data kedua, $\mathrm{P}$ hanya memiliki satu cara penyelesaian tetapi pada pengambilan data keempat (triangulasi), P memilki dua penyelesaian untuk memperoleh hasil yang sama dan mengerjakannya. Ada kecenderungan $\mathrm{P}$ menyukai penyelesaian dengan menggunakan grafik atau bagan terbukti pada pengambilan data pertama dan ketiga, $\mathrm{P}$ menggunakan grafik untuk memberikan cara lain menyelesaikan maslah.

$\mathrm{P}$ menyatakan gambaran dan menyebutkan langkah-langkah penyelesaian masalah dengan lengkap, jelas, terurut dan detail. Selanjutnya, fakta yang ditulis sesuai dengan apa yang disebutkan pada saat wawancara tetapi ia tidak menuliskan unsur lain yang diperlukan dalam penyelesaian masalah. Kemudian $\mathrm{P}$ menyelesaikan masalah sesuai dengan cara yang direncanakan. Ada kecenderungan $\mathrm{P}$ dalam memberikan informasi baik tertulis atau lisan secara detail dan terperinci.

Mahasiswa $\mathrm{P}$ membuat kesimpulan berdasarkan hasil penyelesaiannya. Kesimpulan yang dibuat sesuai dengan hasil penyelesaian tertulisnya. Kemudian, $\mathrm{P}$ mempunyai penyelesaian dengan cara yang berbeda yang dapat mendukung penyelesaian pertamanya, artinya $\mathrm{P}$ mempunyai lebih dari satu penyelesaian. $\mathrm{P}$ meyakini hasil kesimpulan berdasarkan hasil penyelesaian tes tertulisnya.

\section{Simpulan}

Tipe $\mathrm{S}$ cenderung menggunakan simbol-simbol Matematika. $\mathrm{S}$ tidak menjelaskan masalah secara utuh, ia lebih memanfaatkan simbol Matematika sebagai usaha mempresentasikan jawaban pertanyaan tanpa menjelaskan makna dari simbol tersebut. $\mathrm{S}$ mempunyai lebih dari satu cara pada setiap masalah yang diberikan. Ini menunjukkan bahwa $S$ mempunyai ide kreatif dalam memecahkan masalah. Kemudian, $\mathrm{S}$ menyatakan gambaran dan menyebutkan langkah-langkah penyelesaian masalah. S mampu memberikan informasi dengan lengkap, jelas dan terurut. Selain itu, S menyelesaikan masalah sesuai dengan yang rencanakan. Setelah $\mathrm{S}$ menyelesaikan masalah maka $S$ memeriksa kembali hasil penyelesaian tertulisnya. Siswa $\mathrm{S}$ membuat kesimpulan berdasarkan pertanyaan yang diajukan dalam tes tertulis.

Tipe $\mathrm{K}$ tidak mampu menyebutkan kembali unsur-unsur yang diketahui dan ditanyakan pada soal secara lengkap. Akan tetapi, tipe $\mathrm{K}$ mempunyai lebih dari satu cara untuk menyelesaikan masalah dan cenderung memanfaatkan pengalaman. $\mathrm{K}$ tidak memberi gambaran penyelesaian tetapi langsung menyebutkan langkah-langkah penyelesaian masalah secara garis besarnya saja secara singkat. Selain itu, K menyelesaikan masalah sesuai dengan rencana. Siswa $\mathrm{K}$ membuat kesimpulan berdasarkan pertanyaan yang diajukan dalam tes tertulis.

Tipe $\mathrm{M}$ mampu menyebutkan kembali informasi pada soal. Selain itu, $M$ hanya mempunyai satu cara untuk menyelesaikan masalah. Kemudian, $\mathbf{M}$ menyatakan gambaran dan menyebutkan langkah-langkah penyelesaian masalah dengan jelas dan terurut. $\mathrm{M}$ dalam menyampaikan informasi cenderung memerinci masalah dalam bentuk tulisan. Pada saat menyelesaikan masalah $\mathrm{M}$ menyelesaikan masalah sesuai dengan yang rencanakan. Tipe M membuat kesimpulan berdasarkan hasil penyelesaiannya.

Tipe $\mathrm{P}$ mampu menyampaikan unsurunsur dalam masalah dengan lengkap dan jelas, cenderung menggunakan simbol-simbol Matematika yang diikuti makna dari simbol 
tersebut, menyampaikan langkah penyelesaian masalah dengan lengkap dan jelas, mempunyai lebih dari satu cara penyelesaian dengan memanfaatkan pengalamannya, dan cenderung menyukai penyelesaian dengan menggunakan grafik atau bagan. Selain itu, tipe $\mathrm{P}$ menyelesaikan masalah sesuai dengan cara yang direncanakan, serta cenderung memberikan informasi baik tertulis atau lisan secara detail dan terperinci.

\section{Daftar Pustaka}

[1] Arini, A., \& Rosyidi, A. H. (2016). Profil Kemampuan Penalaran Siswa SMP dalam Menyelesaikan Masalah Matematika Ditinjau dari Tipe Kepribadian Extrovert dan Introvert. Jurnal Ilmiah Pendidikan Matematika: Mathedunesa , 2 (5), 127-136.

[2] Jarvis, M. (2012). Teori-Teori Psikologi Pendekatan Modern untuk Perilaku, Perasaan dan Pikiran Manusia. Bandung: Nusa Media.

[3] OECD. (2014). PISA 2012 Results: What Students Know and Can Do. Paris, France: OECD Publications.

[4] Ramdani, Y. (2012). Pengembangan Instrumen dan Bahan Ajar untuk Meningkatkan Kemampuan Komunikasi, Penalaran, dan Koneksi Matematika dalam Konsep Integral. Jurnal Penelitian Pendidikan , 13 (1), 116-129.

[5] Rosita, C. D. (2014). Kemampuan Penalaran dan Komunikasi Matematis: Apa, Mengapa, dan Bagaimana Ditingkatkan pada Mahasiswa. Jurnal Euclid , 1 (1), 33-46.

[6] Sihotang, H. (2011). Pengembangan Desain Pembelajaran Matematika dengan Pendekatan Konstruktivisme Menggunakan Penalaran InduktifDeduktif. Jurnal Dinamika Pendidikan , 4 (2), 94-103.

[7] Subanindro. (2012). Pengembangan Perangkat Pembelajaran Trigonometri Berorientasikan Kemampuan Penalaran dan Komunikasi Matematika Siswa SMA. Seminar Nasional Matematika dan Pendidikan Matematika (pp. 1425). Semarang: Universitas Negeri Semarang.
[8] Suryabrata, S. (2012). Psikologi Pendidikan. Jakarta: PT Rajagrafindo.

[9] Tarigan, H. G. (1987). Berbicara: Sebagai Suatu Keterampilan Berbahasa. Bandung. Bandung: Angkasa Bandung.

\section{Profil Penulis}

Nama, Hafsyah, M. Pd. Dosen pada Program Studi Pendidikan Matematika, Universitas Muhammadiyah Enrekang sejak tahun 2015.

\section{Ucapan Terima Kasih}

Penulis menghaturkan terima kasih dan penghargaan kepada Direktorat Riset dan Pengabdian Masyarakat, Deputi Bidang Penguatan Riset dan Pengembangan, Kementerian Riset dan Teknologi/ Badan Riset dan Inovasi Nasional yang telah membiayai penelitian ini melalui hibah Penelitian Dosen Pemula. Penulis juga mengucapkan terima kasih kepada rekan peneliti, Hasnidar, M. Pd., dan Putriyani S, M. Pd atas kerjasamanya dalam pelaksanaan penelitian ini. 
